\title{
NUTRIENT INTAKE AND RUMEN STUDIES IN GROWING WEST AFRICAN DWARF RAMS FED POLYENZYME TREATED CASSAVA PEEL AND CORN COB BASED DIET
}

\author{
Oluwaseyi Omoniyi Eniolorunda, Oladipupo David Olamilusi*, Mariam Olubunmi Ogunde. \\ Joseph Lomba Uloko
}

\author{
Department of Animal Production, Faculty of Agricultural Production and Renewable Resource, \\ College of Agricultural Sciences, Olabisi Onabanjo University, \\ Ayetoro Campus, Ayetoro, Ogun State, Nigeria \\ *delpoca@gmail.com
}

\begin{abstract}
A b s t r a c t: In order to achieve greater animal protein and improve on feeding management, research conducted on rumen studies in growing West African Dwarf (WAD) rams fed polyenzyme treated cassava peel and corn cob based diet using forty (40) indigenous rams balanced for weight and grouped into four treatments with 10 animals per treatment in a complete randomized design. Inclusion of dried cassava peel meal untreated as $\mathrm{T}_{1}$; corn cob untreated as $\mathrm{T}_{2}$; polyenzyme treated cassava peel as $\mathrm{T}_{3}$ and polyenzyme treated corn cob as $\mathrm{T}_{4}$. The result for feed intake values ware the highest in $T_{3}(13194.76 \mathrm{~g})$, while $\mathrm{T}_{1}(11804.61 \mathrm{~g})$ had the lowest value. Total bacterial and fungi were found to be the highest in $\mathrm{T}_{4}(128.000 \mathrm{cfu} / \mathrm{ml})$ and $\mathrm{T}_{1}$ had the lowest value. Total protozoa were found to be the highest in $\mathrm{T}_{4}$ and $\mathrm{T}_{1}$ had the lowest value. The values for rumen $\mathrm{pH}$ and rumen metabolites were found to be the highest in $\mathrm{T}_{4}$ and $\mathrm{T}_{3}$, while $\mathrm{T}_{1}$ had the lowest value. The value recorded for acetic acid was the highest for $\mathrm{T}_{1}$, while the least value recorded for $\mathrm{T}_{2}$. For butyric acid, $\mathrm{T}_{3}$ tended to have the highest value and $\mathrm{T}_{2}$ had the lowest value. Propionic acid was the highest in $\mathrm{T}_{2}$ and lowest in $\mathrm{T}_{1}$. The microorganism occurrence recorded for bacteria count was the highest in $\mathrm{T}_{4}$ for B. Succinogen, Lactobacillus, Streptococcus p. and R. flavefaciens, while the value obtained for E. coli $(1.5 \mathrm{cfu} / \mathrm{ml})$ was the highest in $T_{3}$. The value recorded for fungi was the highest in $T_{3}(1.5 \mathrm{cfu} / \mathrm{ml})$, while least in $\mathrm{T}_{2}(1.0 \mathrm{cfu} / \mathrm{ml})$. However, protozoa count, $\mathrm{T}_{3}$ tended to have the highest values for Dasyticha, Diplodidium and Isotricha. It was concluded that polyenzyme treated cassava peel and corn cob can be used as dry season feed without inhibiting the microbial activities rather encourages the population and maintain intermediate metabolites in the rumen.
\end{abstract}

Key words: nutrient intake; rumen studies; WAD rams; polyenzyme, diet

\section{ВНЕСУВАЊЕ НА ХРАНЛИВИ МАТЕРИИ И ИСПИТУВАЊА НА РУМЕНОТ НА ЗАПАДНО АФРИКАНСКИ ШУЏЕСТИ ОВНИ ВО ПОРАСТ ХРАНЕТИ СО ИСХРАНА БАЗИРАНА НА ПОЛИЕНЗИМСКИ ТРЕТИРАНА КОРА ОД КАСАВА И ПЧЕНКАРНИ КОЧАНИ}

А п с т р а к т: Со цел да се постигне зголемување на анимални протеини и да се подобри исхраната, спроведено е истражување на руменот кај западноафрикански џуџести овни во пораст хранети со исхрана базирана на полиензимски третирана кора од касава и пченкарни кочани, користејќ четириесет (40) домородни овни слични по тежина и групирани во четири третмани со по 10 животни избрани по случаен избор. Без вклучување на сушен оброк од кора од касава (нетретирани) се означени како $\mathrm{T}_{1}$, нетретирани со кочан од пченка како $\mathrm{T}_{2}$, третирани со полиензимски третирана кора од касава како $\mathrm{T}_{3}$ и третирани полиензимски кочани од пченка како $\mathrm{T}_{4}$. Резултатот за вредностите на внесот на добиточна храна беше највисок во групата $\mathrm{T}_{3}(13194,76$ $\mathrm{g})$, додека $\mathrm{T}_{1}(11804,61 \mathrm{~g})$ имаше најниска вредност. Содржината на вкупните бактерии и габи беше највисока во $\mathrm{T}_{4}(128.000 \mathrm{cfu} / \mathrm{ml})$, a $\mathrm{T}_{1}$ имаше најниска вредност. Утврдено е дека вкупните протозои се највисоки во $\mathrm{T}_{4}$, a $\mathrm{T}_{1}$ имаше најниска вредност. Вредностите на $\mathrm{pH}$ на руменот и метаболитите на руменот беа највисоки кај $\mathrm{T}_{4}$ и $\mathrm{T}_{3}$, додека $\mathrm{T}_{1}$ имаше најниска вредност. Вредноста забележана за оцетна киселина беше највисока за $\mathrm{T}_{1}$ додека најмалата вредност е забележана за $\mathrm{T}_{2}$. За маслената киселина, $\mathrm{T}_{3}$ имаше тенденција за највисока вредност, а $\mathrm{T}_{2}$ имаше најниска вредност. Пропионската киселина беше највисока во Т 2 и најниска во Т 1 . Појавата на микроорганизми регистрирана со бројот на бактерии беше највисока во $\mathrm{T}_{4}$ за B. Succinogen, Lactobacillus, Streptococcus p. и R. Flavefaciens, додека вредноста добиена за E. coli $(1,5 \mathrm{cfu} / \mathrm{ml})$ беше највисока во Т жана за габите беше највисока $(1,5 \mathrm{cfu} / \mathrm{ml})$ кај $\mathrm{T}_{3}$, додека најмала $(1,0 \mathrm{cfu} / \mathrm{ml})$ беше во $\mathrm{T}_{2}$. Но во однос на бројот на протозои, Тз имаше тенденција да има највисоки вредности за Dasytica, Diplodidium и Isotricha. Заклучено е дека лушпата од касава третирана со полиензими и кочанот од пченка можат да се користат како добиточна 
храна во сувата сезона без да се инхибираат микробните активности, а да се подобри популацијата и да се одржат интермедијарните метаболити во руменот.

Клучни зборови: внес на хранливи материи; испитувања на руменот; западноафрикански џуџест овен; полиензими;, исхрана

\section{INTRODUCTION}

Livestock especially ruminant are important components in farming system of southern Nigeria where they play significant roles in adapting to diverse production environment and flexible financial reserve for the rural populace. However, livestock are faced with the challenges of unavailability of feed ingredients to meet up the animal's requirement for optimum production performance. Sheep mostly depend on grasses and legumes which are not available all year round, also low protein quality found in forages during the dry seasons (Akinfemi et. al., 2009; Ekunseitan et. al., 2013).

Therefore, in order to reduce the high cost of conventional feedstuff and balancing ration for the animals with promising productive performance, there is need to introduce the use of crop residues and agro-industrial by-products, which cannot be used as food for humans but as feed for livestock. Nevertheless, literature has shown that in developing countries (including Nigeria) have large quantity of these unconventional feedstuff all year round that are imposing serious environmental hazard (Adeniji and Ehimere, 2003; Ibhaze et. al., 2014). Such by-products comprise of corn cobs, cassava peel, and brewer's grain. Although, feeding the animals with these feedstuffs can limit ruminant productivity and reduce intake by hindering the ruminal functions due to the fibrous nature of the feed (Sarwar et al., 2004).

However, to improve the intake and digestibility of low quality crop residues, incorporation of Gliricidia sepium and enzyme supplementation are useful in reducing the toxicity of cassava peels and break the cell wall by solubilizing hemicellulose, lignin and cellulose bond (Eniolorunda and Rowaiye, 2008; Olamilusi et. al., 2019). This will help in achieving the animal protein insufficiency and improve on feeding management and productive performance since sheep has the tendency to utilized fibrous materials efficiently by its preliminary (Olamilusi et al., 2019). The study aims at examining the optimum utilization and rumen studies in growing West African dwarf rams fed polyenzyme treated cassava peel and corn cob based diet.

\section{MATERIALS AND METHODS}

\section{Study area}

This study was conducted at the Department Animal Production (sheep and goat unit), Teaching and Research Farm, College of Agricultural Sciences, Olabisi Onabanjo University Ayetoro Campus, Ayetoro Ogun State, Nigeria. Ayetoro is located in a deciduous/derived savannah zone of Nigeria at latitude $7^{0} 15^{1} \mathrm{~N}$ and longitude $3^{0} 3^{1} \mathrm{E}$. Climate is sub-humid tropical with an annual rainfall of $1,909.3 \mathrm{~mm}$. Rainy season is between early April and late October. Rainfall pattern is bimodal with two peaks in June and September. Maximum temperature varies between $29^{\circ} \mathrm{C}$ during the peak of the wet season and $34^{\circ} \mathrm{C}$ at the onset of the dry season, and mean annual relative humidity was $81 \%$ (Onakomaiya et al., 1992).

\section{EXPERIMENTAL MANAGEMENT}

A total of 40 (male) indigenous breed of West African dwarf (WAD) sheep were purchased from the local market at Igbogila, Yewa North Ogun state, Nigeria. The animals ranged between 14 and 16 months with an average weight of 13.5 to $15 \mathrm{~kg}$ were used. Prior to the arrival of the animals, the whole pen was swept, washed with water and detergent and also fumigated using strong and active disinfectant at the rate of 1 litre to 200 litres and the floor was covered with wood shavings. The floor was replaced with wood shaving as soon as it is soil with water. The rams were dewormed using Ivomec intramuscular injection at the rate of $0.5 \mathrm{ml}$ per 25 $\mathrm{kg}$ weight; also were vaccinated against Peste des Petite ruminant (PPR) at the rate of $1 \mathrm{ml}$ per $50 \mathrm{~kg}$ weight of animal. Prophylactic antibiotic treatments with oxytetracycline injection, tylosin, streptomycin and penicillin were applied, the quarantine and adjustment lasted for a period of two weeks. During this period, animal were grouped fed with dried cassava peels, Gliricidia sepium and Leucaena leucocephala and clean cool water was offered ad libitum. 


\section{Experimental design}

Animals were allocated into four treatments (designated as $T_{1}, T_{2}, T_{3}$ and $T_{4}$ ) and balanced for weight with 10 animals per treatment in a complete randomized design. Each animal was allotted to individual pen with a size of $1.20 \times 1 \times 1.20$

\section{Feed preparation and feeding regime}

The corn cobs and cassava peels were sourced locally from maize and cassava producers' dried (12\% moisture content) and ground with $6 \mathrm{~mm}$ mesh. Gliricidia sepium was collected within Olabisi Onabanjo University Teaching and Research Farm. Brewers Dried Grain (BDG), wheat offals (WO), oyster shell (OS) and Molasses were obtained from O'Yewa farm Ayetoro. The experimental diet was formulated into four (4) dietary treatments. The feed was offered to the animals twice daily between the 0800 to 1600 hours during the 84-days experiment. The composition of experimental diets is shown in Table 1.

Table 1

Composition of experimental diets (\%)

\begin{tabular}{lcccc}
\hline \hline \multirow{2}{*}{ Ingredients } & \multicolumn{5}{c}{ Dietary treatments } \\
\cline { 2 - 5 } Cassava peels & $\mathrm{T}_{1}$ & $\mathrm{~T}_{2}$ & $\mathrm{~T}_{3}$ & $\mathrm{~T}_{4}$ \\
\hline Corn cobs & 50 & & 49.875 & \\
Gliricidia sepium & 25 & 25 & 25 & 25 \\
Brewers dried grain & 15 & 15 & 15 & 15 \\
Wheat offals & 6 & 6 & 6 & 6 \\
Molasses & 2 & 2 & 2 & 2 \\
Oyster shell & 1 & 1 & 1 & 1 \\
Salt & 1 & 1 & 1 & 1 \\
Poly-enzyme & - & - & 0.125 & 0.125 \\
\hline Total & 100 & 100 & 100 & 100 \\
\hline \hline
\end{tabular}

\section{COLLECTION AND PREPARATION OF RUMEN CONTENT}

\section{Sampling of rumen liquor and contents}

Sixty (60) mls of rumen liquor samples were collected at the end of the experiment from sheep in each treatment with the help of stomach / oesophageal tube of $10 \mathrm{~mm}$ internal diameter after metabolism trial at $0 \mathrm{~h}$ feeding for two consecutive days for determination of rumen $\mathrm{pH}$, rumen metabolites and microbial counts. The samples were preserved by adding a few drops of $20 \%$ sulphuric acid and stored at $-20^{\circ} \mathrm{C}$ until analyzed. Rumen contents sampled at $0 \mathrm{~h}$ feeding was processed immediately for the estimation of rumen metabolite activities (such as acetic, propionic, butyric acids and lactic acid) and rumen microbial profile (Babayemi and Bamikole, 2006). Rumen metabolite analyses were determined by ritrimetryц method - Carolinia method.

\section{Microbiological analyses and isolation of microorganisms}

Test tubes containing $5 \mathrm{mls}$ each of sterile distilled water were labeled with different diluteons. $1 \mathrm{ml}$ of the sample was weighed and then asepticcally introduced into $5 \mathrm{ml}$ of sterile distilled water to give dilution $5-1$, this was then properly shaken. This method of transferring was done until dilution 5-5 was obtained. The media used were Nutrient Agar (NA), Potato Dextrose Agar (PDA) and Mac Conkey Agar (MA). Pure culture was obtained by repeated streaking into freshly prepared agar plates (Buchanan and Gibbon, 1974). The sample rumen content of the experimental animals was obtained for analysis of microbial count such as bacteria, protozoa, and fungi.

\section{Determination of $\mathrm{pH}$}

The $\mathrm{pH}$ of the samples (Rumen liquor) was determined using a $\mathrm{pH}$ meter (model number H198107) that was previously calibrated. $1 \mathrm{~g}$ of the sample was taken, blended and mixed with $10 \mathrm{ml}$ of sterile distilled water. It was thoroughly mixed and then measured with the $\mathrm{pH}$ meter.

\section{Statistical analysis}

Data obtained were subjected to analysis of variance and significant means were separated by Duncan multiple range tests using the procedure of SAS (2002).

\section{RESULTS AND DISCUSSION}

The chemical composition of the experimental diets is shown in Table 2 . The dry matter values are significantly difference $(P<0.05)$ among the treatment. $\mathrm{T}_{3}$ has the highest values, when compared with $T_{1}, T_{4}$ and $T_{2}$ has the least value. There were slightly different in the crude protein content among the treatment. $T_{2}$ and $T_{4}$ tends to have the highest 
values followed by $T_{3}$ and $T_{1}$ having the least values. $T_{2}$ has the highest values and $T_{1}$ the lowest values of crude fibre. The ash and ether extract values were the highest in $T_{3}$ followed by $T_{4}$ and the lowest in $\mathrm{T}_{2}$, respectively. The value recorded for carbohydrate was Txe highest in $\mathrm{T}_{2}(66.38)$ and $\mathrm{T}_{4}$ (66.20) and the lowest in $T_{1}$ (64.83). The values recorded for NDF were the highest in $\mathrm{T}_{2}$ having the highest values, follows $T_{3}$ and $T_{1}$, while $T_{4}$ has the least. However, $T_{1}$ tends to have the lowest values of ADF.

\section{Table 2}

Chemical composition of the complete mixed ration.

\begin{tabular}{lcrrrrl}
\hline \multirow{2}{*}{ Parameters } & \multicolumn{5}{c}{ Dietary treatments } & \\
\cline { 2 - 5 } & \multicolumn{1}{c}{$\mathrm{T}_{1}$} & \multicolumn{1}{c}{$\mathrm{T}_{2}$} & \multicolumn{1}{c}{$\mathrm{T}_{3}$} & \multicolumn{1}{c}{$\mathrm{T}_{4}$} & SEM \\
\hline Dry matter & $87.24^{\mathrm{b}}$ & $86.74^{\mathrm{c}}$ & $88.25^{\mathrm{a}}$ & $87.22^{\mathrm{b}}$ & 0.26 \\
Crude protein & $11.02^{\mathrm{c}}$ & $11.87^{\mathrm{a}}$ & $11.40^{\mathrm{b}}$ & $11.75^{\mathrm{a}}$ & 0.31 \\
Crude fibre & $4.08^{\mathrm{c}}$ & $5.70^{\mathrm{a}}$ & $4.80^{\mathrm{b}}$ & $5.14^{\mathrm{b}}$ & 1.01 \\
Ash & $2.05^{\mathrm{a}}$ & $1.98^{\mathrm{c}}$ & $2.17^{\mathrm{a}}$ & $2.08^{\mathrm{a}}$ & 0.04 \\
Ether extract & $2.69^{\mathrm{c}}$ & $2.59^{\mathrm{c}}$ & $2.97^{\mathrm{a}}$ & $2.84^{\mathrm{b}}$ & 0.07 \\
Carbohydrate & $64.83^{\mathrm{c}}$ & $66.38^{\mathrm{a}}$ & $65.93^{\mathrm{b}}$ & $66.20^{\mathrm{a}}$ & 0.27 \\
Energy & $17.49^{\mathrm{a}}$ & $17.30^{\mathrm{b}}$ & $17.39^{\mathrm{ab}}$ & $16.69^{\mathrm{c}}$ & 0.15 \\
NDF & $74.42^{\mathrm{c}}$ & $78.54^{\mathrm{a}}$ & $75.70^{\mathrm{b}}$ & $73.11^{\mathrm{d}}$ & 1.15 \\
ADF & $48.45^{\mathrm{b}}$ & $50.74^{\mathrm{a}}$ & $49.13^{\mathrm{ab}}$ & $50.13^{\mathrm{ab}}$ & 0.75 \\
ADL & $15.89^{\mathrm{d}}$ & $21.47^{\mathrm{a}}$ & $18.09^{\mathrm{c}}$ & $20.35^{\mathrm{b}}$ & 0.89 \\
\hline \hline
\end{tabular}

a, b, c Means within the same row differing in superscripts are significantly different $(P>0.05)$

The ranged values obtained for dry matter (86.74-88.25) were in similar to Fajemisin et. al., (2015), which test for response of West African dwarf sheep to differently processed corn cob meal based diets. But lower than the values obtained from Eniolorunda and Rowaiye (2008) when corn husk supplemented with cassava leaf or Leucaena leaf meal based diet to feed Yankassa sheep. The crude protein of the experimental diets was adequate and higher than the minimum requirement of $8 \%$ and within the range 14-18\% recommended for ruminants body maintenance (Norton, 2003; ARC, 1985). The decreased in the fibre fractions of the poly-enzyme treated mixed ration is due to probably the enzymatic action on the experimental diets. These agree with report of Belewu and Popoola (2007) when WAD sheep was fed with rhizopus treated sawdust. There was significant difference $(p$ $<0.05)$ in the NDF and ADF among the treatment.
These values were in correlation with Fajemisin et al. (2012b) when ensiled corn cobs treated with or without water, lye and urea were fed to West African dwarf sheep. The crude fibre obtained would be adequate to meet the fibre requirement of the animals.

The nutrient intake of the experimental diets is shown in Table 3. All parameters were significantly difference among the treatment. All the parameters recorded across the treatments were the highest for $T_{3}$, followed by $T_{4}, T_{2}$ and $T_{1}$, had the lowest values.

Table 3

Nutrient intake by West African dwarf sheep fed of the experimental diets

\begin{tabular}{lrrrrr}
\hline \hline Parameter & \multicolumn{1}{c}{$\mathrm{T}_{1}$} & \multicolumn{1}{c}{$\mathrm{T}_{2}$} & \multicolumn{1}{c}{$\mathrm{T}_{3}$} & \multicolumn{1}{c}{$\mathrm{T}_{4}$} & $\mathrm{SEM}$ \\
\hline Dry matter & $140.29^{\mathrm{d}}$ & $150.78^{\mathrm{c}}$ & $165.36^{\mathrm{a}}$ & $155.59^{\mathrm{b}}$ & 3.40 \\
Crude Protein & $17.17^{\mathrm{c}}$ & $17.31^{\mathrm{c}}$ & $20.44^{\mathrm{a}}$ & $18.47^{\mathrm{b}}$ & 0.49 \\
Crude Fibre & $7.01^{\mathrm{c}}$ & $7.51^{\mathrm{c}}$ & $9.82^{\mathrm{a}}$ & $8.33^{\mathrm{b}}$ & 0.40 \\
Ether Extract & $3.93^{\mathrm{d}}$ & $4.07^{\mathrm{c}}$ & $5.12^{\mathrm{a}}$ & $4.60^{\mathrm{b}}$ & 0.13 \\
Ash & $2.10^{\mathrm{d}}$ & $3.11^{\mathrm{c}}$ & $3.73 \mathrm{a}$ & $3.37^{\mathrm{b}}$ & 0.22 \\
NFE & $96.34^{\mathrm{c}}$ & $104.26^{\mathrm{b}}$ & $111.66^{\mathrm{a}}$ & $107.29^{\mathrm{b}}$ & 5.98 \\
Energy & $25.41^{\mathrm{c}}$ & $27.17^{\mathrm{b}}$ & $30.13^{\mathrm{a}}$ & $27.05^{\mathrm{b}}$ & 0.64 \\
NDF & $110.62^{\mathrm{d}}$ & $123.36^{\mathrm{b}}$ & $128.19^{\mathrm{a}}$ & $118.49^{\mathrm{c}}$ & 2.45 \\
ADF & $71.80^{\mathrm{d}}$ & $79.69^{\mathrm{b}}$ & $83.46^{\mathrm{a}}$ & $81.25^{\mathrm{b}}$ & 1.66 \\
ADL & $26.44^{\mathrm{c}}$ & $33.72^{\mathrm{a}}$ & $27.37^{\mathrm{b}}$ & $33.06^{\mathrm{a}}$ & 1.24 \\
\hline \hline a,b,c, d Means within the same row differing in superscripts are \\
\multicolumn{2}{c}{ significantly different $(P>0.05)$} & & & \\
& & &
\end{tabular}

The highest DM and CP intake values obtained for sheep fed $T_{3}$ (165.36 and 20.44) were influenced by the inclusion level of cassava peel treated with polyenzyme. This could be a result of high level protein and low fibre content in the diet which influenced microbial protein synthesis, enhancing fermentation and consequently improved intake. However, it was agreed by Fajemisin (1994) that corn cob treated with poultry litter and urea would enhanced microbial fermentation and improves gut fill of small ruminants. The high value recorded for $\mathrm{T}_{3}$ and $\mathrm{T}_{4}$ (cassava peel treated polyenzyme and corn cob treated polyenzyme) diet is as a reflection of polyenzyme inclusion than other diet which encourage easy digestion of the feed. This was in support with Khan et al. (2004) that high CP intake might be due to the inclusion of non-protein nitrogen that enhanced microbial activities in the rumen of the sheep. The increase in energy, NDF, ADF and ADL also followed this trend in $\mathrm{T}_{3}$ having the highest values. 
Nisa et al. (2004) also have similar higher intake of NDF and ADF in lactating cows fed urea-treated corn cob, which attributed to higher nutrient intake and improved digestibility of fibre fractions. This result obtained in the study shows that NDF, ADF and ADL intake attributed to improved protein content with the percentage inclusion of polyenzyme to the diet.

The nutrient intake and microbial activities of the experimental diets are shown in Table 4. All parameters were significantly differented among the treatment. The feed intake values were significantly differenced $(\mathrm{p}<0.05)$ among the treatment, $\mathrm{T}_{3}$ (13194.76) tends to have the highest value, followed by $\mathrm{T}_{4}(12917.92)$, while $\mathrm{T}_{1}$ (11804.61) having the lowest value. Total bacteria, was found to be the highest in $T_{4}$ (128.000), followed by $T_{3}, T_{2}$, and $T_{1}$ had the lowest values. The value recorded for total fungi was the highest in $T_{4}$, and $T_{3}$ and the lowest in $\mathrm{T}_{1}$. Total protozoa values obtained were the highest in $T_{4}$, followed by $T_{2}, T_{3}$ and $T_{1}$, respectively.

Table 4

Effect of dietary treatments on feed intake and microbial activities in growing sheep fed total mixed ration

\begin{tabular}{lccccc}
\hline \hline Parameter & $\mathrm{T}_{1}$ & $\mathrm{~T}_{2}$ & $\mathrm{~T}_{3}$ & $\mathrm{~T}_{4}$ & SEM \\
\hline Feed intake & $11804.61^{\mathrm{d}}$ & $12008.61^{\mathrm{c}}$ & $13194.76^{\mathrm{a}}$ & $12917.92^{\mathrm{b}}$ & 222.069 \\
Total bacteria & $40.50^{\mathrm{d}}$ & $58.00^{\mathrm{c}}$ & $106.50^{\mathrm{b}}$ & $128.00^{\mathrm{a}}$ & 15.380 \\
Total fungi & $33.50^{\mathrm{d}}$ & $46.00^{\mathrm{c}}$ & $103.00^{\mathrm{b}}$ & $108.00^{\mathrm{a}}$ & 15.928 \\
Total protozoa & $27.50^{\mathrm{d}}$ & $45.00^{\mathrm{b}}$ & $39.50^{\mathrm{c}}$ & $53.66^{\mathrm{a}}$ & 5.274 \\
\hline \hline
\end{tabular}

a, b, c, d Means within the same row differing in superscripts are significantly different $(P>0.05)$

From the results, it was indicated that animals fed with inclusion of treated polyenzyme cassava peel and corn cob tend to have high feed intake, this might cause easy pretension and digestion by the microorganism in the rumen of the animal. This was in accordance with Ngwa and Tawah (2002) and Fasae and Alokan (2006) that supplemented cassava peel based diets with urea will increase feed intake and protein digestibility in ruminants systems. Also, in the study of Eniolorunda and Rowaiye (2008) that the use of enzyme supplementation may be useful in reducing the toxicity of cassava peels and also making con cob's nutrient digestible to animals. The higher occurrence in the total bacteria values obtained for enzyme treated cassava peel $\left(\mathrm{T}_{3}\right)$ and corn cob $\left(\mathrm{T}_{4}\right)$ could be attributed to the polyenzyme treatment which probably enhanced the population and activities microbes present in the rumen. Yoon and Stern (1995) reported that feed supplements stimulate ruminal bacteria and have a positive effect on various digestive processes, especially cellulolysis and synthesis of microbial protein in adult ruminants. Also, Singh (2004) resulting in optimum metabolites concentration for conductive rumen environment for multiplication and proliferation of bacteria. According to Orpin (1977) was in agreement that apart from bacteria and protozoa, rumen fungal population is also affected by physical and chemical makeup of diets. It was suggested that supplementation of diets with degradable factors tends to increase bacteria activities in the rumen.

The rumen $\mathrm{pH}$ and the rumen metabolites of the experimental diets fed to sheep are shown in Table 5 .

\section{Table 5}

\section{Effect of dietary treatment on the rumen $\mathrm{pH}$ and the rumen metabolites of sheep fed total mixed ration}

\begin{tabular}{lccccc}
\hline \hline Parameter & $\mathrm{T}_{1}$ & $\mathrm{~T}_{2}$ & $\mathrm{~T}_{3}$ & $\mathrm{~T}_{4}$ & $\mathrm{SEM}$ \\
\hline $\mathrm{pH}$ value & $6.26^{\mathrm{c}}$ & $6.40^{\mathrm{b}}$ & $6.45^{\mathrm{a}}$ & $6.48^{\mathrm{a}}$ & 0.25 \\
Acetic acid & $2.347^{\mathrm{b}}$ & $1.493^{\mathrm{d}}$ & $3.070^{\mathrm{a}}$ & $1.642^{\mathrm{c}}$ & 0.25 \\
Butyric acid & $0.133^{\mathrm{b}}$ & $1.064^{\mathrm{c}}$ & $0.183^{\mathrm{a}}$ & $0.107^{\mathrm{c}}$ & 0.24 \\
Propionic acid & $0.260^{\mathrm{d}}$ & $0.756^{\mathrm{a}}$ & $0.438^{\mathrm{c}}$ & $0.622^{\mathrm{b}}$ & 0.11 \\
Lactic acid & $0.367^{\mathrm{c}}$ & $0.540^{\mathrm{b}}$ & $1.194^{\mathrm{a}}$ & $0.309^{\mathrm{d}}$ & 0.22 \\
\hline \hline \\
$\begin{array}{l}\mathrm{a}, \mathrm{b}, \mathrm{c}, \mathrm{d} \\
\text { Means within the same row differing in superscripts are } \\
\text { significantly different }(P>0.05)\end{array}$
\end{tabular}

All evaluated parameters were significantly ( $\mathrm{p}$ $<0.05$ ) affected by dietary treatments. The value for $\mathrm{pH}$ in $\mathrm{T}_{4}$ compared favorably with $\mathrm{T}_{3}$, while $\mathrm{T}_{1}$ had the lowest value. The value recorded for acetic acid was the highest for $T_{3}$, followed by $T_{1}, T_{4}$, and $T_{2}$ has the least value. For butyric acid, $\mathrm{T}_{2}$ tends to have 
the highest values, followed by $\mathrm{T}_{3}$, while $\mathrm{T}_{4}$ compared favorably with and $\mathrm{T}_{2}$ has the lowest value. Propionic acid was the highest in $\mathrm{T}_{2}$ and lowest in $\mathrm{T}_{1} . \mathrm{T}_{3}$ tends to have the highest record for lactic acid, whereas $T_{2}$ follows and $T_{4}$ is the least.

The $\mathrm{pH}$ values obtained in the present study were influence by the diets. This was in accordance with Muia et al. (2000) who reported that the values of $\mathrm{pH}$ were in the range of 6.3 to 7.0. The values obtained in the present study for $\mathrm{pH}$ accordance to be conducive for the rumen microbes (fauna) and also enhanced faunation in the rumen. This is in agrement with the earlier study of Khaing et. al. (2016) who reported that the value for $\mathrm{pH}$ ranged from 6.0 to 7.0, was considered optimal for the activity of rumen microbial population for their growth. A high proportion of acetic acid, butyric acid and lactic acid were recorded in $\mathrm{T}_{3}$, which recorded low propionic acid level. This is in accordance with Firkins et al. (2006), who reported that the high percentage of the intermediate metabolites produced in the rumen depends largely on the composition of diets consumed by the ruminant in particular the fractions contained in the feed. However, in the present study, high level of acetic, butyric and lactic acids recorded were observed in animals fed dietary treatment three $\left(\mathrm{T}_{3}\right)$. This was in accordance with earlier finding by Leedle et al. (1995), who stated that the proportion of intermediate metabolites considerably increased when the diet is changed from a low energy diet to a high energy diet.

The mean occurrences of microorganism isolates from the rumen liquor is shown in Table 6. The value recorded for bacteria counts was significant different $(P<0.05)$ across the treatments. It was recorded that $\mathrm{T}_{4}$ has the highest values for $B$. Succinogen (2.0), Lactobacillus (3.3), Streptococcus p. (1.6) and $R$. flavefaciens (2.1). while the value obtained for E. coli (1.5) was the highest in $\mathrm{T}_{3}$. The value recorded for fungi was the highest in $\mathrm{T}_{3}(1.5)$, followed by $\mathrm{T}_{4}$ (1.4), $\mathrm{T}_{1}$ (1.1), while the least value obtained for $\mathrm{T}_{2}$ (1.0). However, for protozoa count, $\mathrm{T}_{3}$ tends to have the highest values for Dasyticha (3.0), Diplodidium (3.2) and Isotricha (1.2), while $\mathrm{T}_{3}$ compared significant $(P>0.05)$ with $\mathrm{T}_{4}$ for Entodinium and Epidinium.

The rumen cellulolytic bacteria microbes present in this present study showed greater degradation of fibre. This is in support of Khaing (2016), who reported that some various rumen cellulolytic bacteria have better capacity to degrade fibre materials. It was also recorded in the present study, that there were increase occurrences of B. succinogen,
Lactobaccillus, $S$. pneumonia and $R$. flavefaciens were comparable among the dietary treatments. The highest numbers of bacteria occurrences were found in $T_{3}$, and $T_{4}$. This could probably due to polyenzyme treatment on the diets which enhanced microbes' population to effectively degrade the feed materials. However, according to Collings and Yokoyama (1980), who reported that hemicellulose was degraded by $R$. flavefaciens and $F$. succinogen with the same pattern of degradation; however, the proliferation of microbes might probably be interactive effect of their physical and chemical constituents of the mixed diets. However, it was noted that the highest protozoa count comprises of Dasyticha, Diplodidium, Entodinium, Epidinium and Isotricha were observed in $\mathrm{T}_{3}$ and $\mathrm{T}_{4}$ diets.

\section{Table 6}

Occurrence of microorganism isolates from the rumen liquor of sheep fed total mixed ration

\begin{tabular}{lccccc}
\hline \hline \multirow{2}{*}{ Organisms } & \multicolumn{5}{c}{ Treatments } \\
\cline { 4 - 6 } & $\mathrm{T}_{1}$ & $\mathrm{~T}_{2}$ & $\mathrm{~T}_{3}$ & $\mathrm{~T}^{4}$ & SEM \\
\hline Bacteria $\times 10^{6}$ & & & & & \\
B. succinogen & $0.7^{\mathrm{c}}$ & $0.9^{\mathrm{c}}$ & $1.4^{\mathrm{b}}$ & $2.0^{\mathrm{a}}$ & 0.17 \\
E. coli & $1.1^{\mathrm{c}}$ & $1.0^{\mathrm{d}}$ & $1.5^{\mathrm{a}}$ & $1.4^{\mathrm{b}}$ & 0.07 \\
Lactobaccillus & $1.4^{\mathrm{c}}$ & $1.5^{\mathrm{c}}$ & $2.7^{\mathrm{b}}$ & $3.3^{\mathrm{a}}$ & 0.13 \\
S. pneumonia & $0.9^{\mathrm{b}}$ & $1.1^{\mathrm{b}}$ & $1.4^{\mathrm{a}}$ & $1.6^{\mathrm{a}}$ & 0.20 \\
R. flavefaciens & $1.2^{\mathrm{c}}$ & $1.1^{\mathrm{c}}$ & $1.6^{\mathrm{b}}$ & $2.1^{\mathrm{a}}$ & 0.17 \\
Fungi & $2.1^{\mathrm{c}}$ & $1.8^{\mathrm{d}}$ & $2.7^{\mathrm{a}}$ & $2.4^{\mathrm{b}}$ & 0.21 \\
Protozoa $\times 10^{5}$ & & & & & \\
Dasyticha & $2.2^{\mathrm{c}}$ & $1.9^{\mathrm{d}}$ & $3.0^{\mathrm{a}}$ & $2.9^{\mathrm{b}}$ & 0.23 \\
Diplodidium & $2.0^{\mathrm{c}}$ & $1.6^{\mathrm{d}}$ & $3.2^{\mathrm{a}}$ & $2.2^{\mathrm{b}}$ & 0.12 \\
Entodinium & $0.9^{\mathrm{c}}$ & $1.2^{\mathrm{b}}$ & $1.5^{\mathrm{a}}$ & $1.4^{\mathrm{a}}$ & 0.11 \\
Epidinium & $0.8^{\mathrm{b}}$ & $0.7^{\mathrm{c}}$ & $1.2^{\mathrm{a}}$ & $1.3^{\mathrm{a}}$ & 0.11 \\
Isotricha & $0.8^{\mathrm{d}}$ & $0.9^{\mathrm{c}}$ & $1.2^{\mathrm{a}}$ & $1.1^{\mathrm{b}}$ & 0.07 \\
\hline \hline
\end{tabular}

a, b, c, d Means within the same row differing in superscripts are significantly different $(P>0.05)$

The results of the present study might be probably due to the treatment effect (polyenzyme) on the diets influences the protozoa count. This was also in accordance with Dennis et al. (1983), who reported that the number of rumen protozoa population increased due to regulates rate of starch fermentation in the rumen. However, Brown et al. (2006) also stated that low number of protozoa population in high starch level diets would be expected to enhance the growth of amylolytic bacteria and rapid production of organic acid 


\section{CONCLUSION}

From the results, it was concluded that polyenzyme treated cassava peel and corn cob can be used as a diet for dry season feed without inhibiting the microbial activities. However, encourages the total bacterial population, maintain rumen intermediate metabolites and enhanced protozoa population in the rumen.

\section{REFERENCES}

Adeniji, A. A., Ehimere, S. (2003): Effect of replacing maize with sorghum offal in the diets of weaner rabbits. J. Agric. Res. Dev. 2, 1-6.

Akinfemi, A., Adu, O. A., Aya, V. E. (2009): Use of an in vitro gas production Techniques to evaluate some Nigerian feedstuff. American-Eurasian Journal of Scientific Research, 4 (4), 240-245.

ARC (1985): The nutrient requirements of farm animals, No. 20: Ruminants Tech Rev and Summaries. Agricultural Research Council, London.

Babayemi, O. J., Bamikole, M. A. (2006): Effect of Tephrosia Candida D C leaf and its mixtures with Guinea grass on in vitro fermentation changes as feed on ruminants in Nigeria. Pakistan Journal of Nutrition, 5 (1),14-18.

Brown, M. S., Ponce, C. H., Pulikanti, R. (2006): Adaptation of beef cattle to high-concentrate diets: Performance and ruminal metabolism. J. Anim. Sci., 84, 25-33.

Carberry, C. A., Kenny, D. A., Han, S., McCabe, M.S., Waters, S. M. (2012): Effect of phenotypic residual feed intake and dietary forage content on the rumen microbial community of beef cattle. Applied Environ. Microbiol., 78,: 49494958.

Collings, G. F., Yokoyama, M. T. (1980): Gas-liquid chromatography for evaluating polysaccharide degradation by Ruminococcus flavefaciens and Bacteroides succinogenes S85. Applied Environ. Microbiol, 39,: 566-571.

Dennis, S. M., Arambel, M. J., Bartley, E. E., Dayton, A. D. (1983): Effect of energy concentration and source of nitrogen on numbers and types of rumen protozoa. J. Dairy Sci. 66, $1248-1254$.

Ekunseitan, D. A., Yusuf, A. O, Odesanmi, A. F. (2013): Assessment of nutritive values of some waterweeds. Food Science and Quality Management, Vol. 22, pp. 22-27.

Eniolorunda, O. O., Rowaiye, G. A. (2008): Effect of solubilization on corn husk supplementation with cassava leaf or leucaena leaf meal based diet on feed intake and digestion in Yankassa sheep. Res. Jour. of Ani. Sci. 2 (6), 164-169.

Fajemisin, A. N., Chineke, C. M., Fadiyimu, A. A., Fajemisin, A. J. (2015): Response of West African dwarf sheep to differently processed corncob meal based diets. Nigerian Journal of Animal Production 42 (1), 162-170.

Fasae, O. A., Alokan, J. A. (2006): Growth performance of weaner Yankasa sheep fed varying levels of Leucaena leucocephala leaf residues. Assets Series A. Vol. 6 (2), 323-328.
Firkins, J. L., Hristov, A. N., Hall, M. B., Varga, G. A., StPierre, N. R. (2006): Integration of ruminal metabolism in dairy cattle. J. Dairy Sci. 89, E31-E51.

Ibhaze, G. A., Babayemi, O. J., Olorunnisomo, O. A. (2014): Acceptability and digestibility of ensiled mixtures of corncobs, cassava peels and brewers' grain by West African Dwarf goat. Nigerian Society for Animal Production, 41 (2), 139-145.

Khaing, K. T., Loh, T. C., Ghizan, S., Jahromi, M. F., Halim, R. A., Samsudin, A. A. (2016): Profiling of rumen fermentation and microbial population changes in goats fed with napier grass supplemented with whole corn plant silage. Asian Journal of Animal Sciences, Vol. 10 (1): 114.

Khampa, S., Wanapat, M., Wachirapakorn, C., Nontaso, N., Wattiaux, M. A., Rowlison, P. (2006): Effect of levels of sodium DL-malate supplementation on ruminal fermentation efficiency of concentrates containing high levels of cassava chip in dairy steers. Aisan Aust. J. Anim. Sci. 19, 368-375.

Leedle, J. A., Coe, M. L., Frey, R. A. (1995): Evaluation of health and ruminal variables during adaptation to grainbased diets in beef cattle. Am. J. Vet. Res. 56, 885-892.

Muia, J. M. K., Tamminga, S., Mbugua, P. N., Kariuki, J. N. (2000): The nutritive value of Napier grass (Pennisetum purpureum) and its potential for milk production with or without supplementation: A review. Trop. Sci., 40, 109131.

Ngwa, A.T. and Tawah, C. L. (2002): Effect of supplementation with leguminous crop residues or concentrates on voluntary intake and performance of Kirdi sheep. Tropical Animal Health and Production. 34, 65-73.

Norton, B. W. (2003): The Nutritive values of trees legumes as dietary supplement for ruminants. In: Forage Tree Legumes in Tropical Agriculture. Editors Gutterridge, R. C. and Shelton, H. M., pp 171-191.

Olamilusi, O. D., Olotu, J. D. and Eniolorunda, O. O. (2019): Dry matter acceptability and digestibility of nutrient by West African dwarf rams fed polyenzyme treated cassava peel and corn cob based diets. Nig. J. Anim. Prod. 46 (2), 202-208.

Onakomaiya, S. O., Oyesiku, K. A., Jegede, S. J. (1992): Ogun State in Maps. First ed. Rex. Charles publication, Ibadan.

Orpin C. G. (1977): On the induction of zoosporogenesis in the phycomycetes Neocallimastix frontalis, Piromonas communis and Sphaeromonas communis. Journal of General Microbiology 101, 181-189.

SAS, Statistical Analysis Institute (2002): Users Guide. Statistical Analysis Institute, Inc, Carry North Caroline, USA.

Singh S. (2004): Metabolic and Rumen Microbial Activities in Sheep and Goats on grass-tree leaves/shrubs dietary regimes. Technical Bulletin. Indian Grassland and Fodder Research Institute, Jhansi, India.

Yoon, I. K., Stern, M. D. (1995): Influence of direct-fed microbials on ruminal microbial fermentation and performance of ruminants - A review. Asian-Aust. J. Anim. Sci. 8, 533555 
